\title{
Propineb efficiency in controlling downy mildew of onion under field conditions
}

\author{
E. R. Araújo ${ }^{1}$ (D) - R. S. Resende ${ }^{1}$ \\ Received: 25 May 2020 / Accepted: 13 August 2020 / Published online: 17 August 2020 \\ (C) Australasian Plant Pathology Society Inc. 2020
}

\begin{abstract}
Downy mildew of onion has worldwide occurrence. This study aimed to evaluate the effect of weekly sprays of different active ingredients on the area under a disease progress curve (AUDPC) and on the commercial yield of onion, under field conditions. We observed that propineb sprays resulted in the highest values of yield in $2017\left(32.98 \mathrm{tha}^{-1}\right)$ and $2018\left(20.70 \mathrm{tha}^{-1}\right)$. Propineb (130.66) and metalaxyl-M + mancozeb (144.66) presented the lowest AUDPC values in 2017. Metalaxyl-M $\left(100 \mathrm{~g} \mathrm{ha}^{-1}\right)+$ mancozeb $\left(1600 \mathrm{~g} \mathrm{ha}^{-1}\right)$, bentiavalicarb-isopropyl $\left(56.25 \mathrm{~mL} \mathrm{ha}^{-1}\right)+$ chlorothalonil $\left(562.5 \mathrm{~mL} \mathrm{ha}^{-1}\right)$ and bentiavalicarbisopropyl $\left(40 \mathrm{~mL} \mathrm{ha}^{-1}\right)+$ fluazinam $\left(100 \mathrm{~mL} \mathrm{ha}^{-1}\right)$ resulted in higher yields than the control (water) in the two years of testing. We emphasise the importance of using fungicides with protective action to control downy mildew of onion.
\end{abstract}

Keywords Allium cepa $\cdot$ Peronospora destructor $\cdot$ Chemical control

Onion (Allium cepa) is the main vegetable grown in Santa Catarina, Brazil. The state is the largest national producer of onion, with a production of about $432,000 \mathrm{t}$ in the $2017 / 18$ crop season (Epagri/Cepa 2018). Downy mildew, caused by Peronospora destructor, is a major foliar disease of onions, especially in southern Brazil. There are no resistant commercial cultivars to $P$. destructor in Brazil, and the use of fungicides (mainly metalaxyl-M, mancozeb, and chlorothalonil) is the primary control method. This study aimed to evaluate the efficiency of different active ingredients in controlling downy mildew of onion, under field conditions, in the 2017/18 and 2018/19 crop seasons.

The trials were carried out at the Epagri Experimental Station, in Ituporanga, Santa Catarina, Brazil. The cultivar "Empasc 352 - Bola Precoce", known to be susceptible to downy mildew (Alves et al. 2018), was used in both years. Downy mildew epidemics were started by natural infection. Symptomatology and presence of structures (sporangia and sporangiophores) observed under a stereoscopic loupe (60 and 80 days after transplanting) were used in order to confirm the disease occurrence. Samples

E. R. Araújo

edivanioaraujo@epagri.sc.gov.br

1 Epagri - Estação Experimental de Ituporanga, Ituporanga, SC 88400-000, Brazil of $P$. destructor were sent to the FLOR herbarium (FLOR 67946) located in Florianópolis, Santa Catarina, Brazil. Onion seedlings were grown on a soil bed and approximately 60 days after sowing, they were transplanted to the experimental area. The experimental plots consisted of 120 plants (six rows with 20 plants) arranged in a spacing of $0.10 \mathrm{~m}$ (between plants) and $0.40 \mathrm{~m}$ (between rows), simulating a plant density of approximately 250,000 plants per hectare. All cultural practices were performed as recommended (Epagri 2013; Kurtz et al. 2018).

In the 2017 trial, the treatments (weekly sprays using manual pressure sprayers) were as follows: T1 - propineb (2100 $\left.\mathrm{g} \mathrm{ha}^{-1}\right)$; T2 - metalaxyl-M (100 $\left.\mathrm{g} \mathrm{ha}^{-1}\right)+$ mancozeb $\left(1600 \mathrm{~g} \mathrm{ha}^{-1}\right)$; T3 - bentiavalicarb-isopropyl $\left(56.25 \mathrm{~mL} \mathrm{ha}^{-1}\right)+$ chlorothalonil $\left(562.5 \mathrm{~mL} \mathrm{ha}^{-1}\right)$; $\mathrm{T} 4-$ bentiavalicarb-isopropyl $\left(30 \mathrm{~mL} \mathrm{ha}^{-1}\right)+$ fluazinam (75 mL ha $\left.{ }^{-1}\right)$; T5 - bentiavalicarb-isopropyl $\left(40 \mathrm{~mL} \mathrm{ha}^{-1}\right)+$ fluazinam $\left(100 \mathrm{~mL} \mathrm{ha}{ }^{-1}\right) ; \mathrm{T} 6$ - $\beta$-aminobutyric acid $\left(250 \mathrm{~g} \mathrm{ha}^{-1}\right)$; $\mathrm{T} 7$ - $\beta$-aminobutyric acid $\left(500 \mathrm{~g} \mathrm{ha}^{-1}\right)$; T8 - $\beta$ aminobutyric acid $\left(1000 \mathrm{~g} \mathrm{ha}^{-1}\right)$; T9 - pyroligneous extract (500 $\left.\mathrm{mL} \mathrm{ha}^{-1}\right)$; T10 - water (control). In 2018, based on the 2017 results, we reassessed the treatments T1; T2; T3; T5; T7; T10, and another treatment not previously evaluated [alternative control: Eco Shock $®\left(2 \mathrm{~kg} \mathrm{ha}^{-1}\right)$, Intrax Cobre® (400 mL ha $\left.{ }^{-1}\right)$, Eco Avaster® $\left(750 \mathrm{~mL} \mathrm{ha}^{-1}\right)$, Eco Zidook® (300 $\mathrm{mL} \mathrm{ha}^{-1}$ ) and Intrax Mix ${ }^{\circledR}\left(350 \mathrm{~mL} \mathrm{ha}^{-1}\right)$, which contained phosphoric acid, copper-phosphite, quaternary ammonium, polymeric biguanide, acetylsalicylic acid, in 
concentrations not reported by the manufacturer]. The treatments started 25 days after transplanting. We performed 10 sprays in 2017, and 12 in 2018. The spray volume applied for all treatments corresponded to $500 \mathrm{~L} \mathrm{ha}^{-1}$.

The severity was assessed fortnightly using a rating description scale (1-9), which assigns scores to the entire plot (Mohibullah 1991). The values from scale scores of the experimental plots were used to calculate the area under a disease progress curve - AUDPC (Shaner and Finney 1977). The harvest was carried out 103 days after transplanting in 2017, and 110 days after transplanting in 2018. Commercial yield (onion bulbs with diameter $\geq 35 \mathrm{~mm}$ ) was calculated from the central rows of each plot, 14 days after harvest, discarding single border rows. The experiments were randomised in blocks designed with three replications. The data were analysed using ANOVA and, in case of significance of the treatments, means were grouped with Scott-Knott cluster. The software Sisvar v. 5.6 (Ferreira 2011) was used for all analyses.

Propineb sprays resulted in the highest yield in the two years of testing $(99.8 \%$ and $63.0 \%$ more than the control plot in 2017 and 2018, respectively), although no statistically significant difference was observed for AUDPC among treatments assessed in 2018 (Table 1). Applications of metalaxyl-M + mancozeb $(58.9 \%$ in 2017 , and $32.5 \%$ in 2018), bentiavalicarb-isopropyl + chlorothalonil $(40.3 \%$ in 2017 , and $30.3 \%$ in 2018) and bentiavalicarb-isopropyl $\left(40 \mathrm{~mL} \mathrm{ha}^{-1}\right)+$ fluazinam $\left(100 \mathrm{~mL} \mathrm{ha}^{-1}\right)(25.1 \%$ in 2017 , and $22.0 \%$ in 2018) resulted in higher yield than the control plot in both years. The other treatments, including alternative control (Eco Shock ${ }^{\circledR}$, Intrax Cobre ${ }^{\circledR}$, Eco Avaster ${ }^{\circledR}$, Eco Zidook ${ }^{\circledR}$ and Intrax Mix $\left.{ }^{\circledR}\right)$, did not differ from the control (water).

The yields were higher in 2017 compared to 2018. This difference can be partially explained by weather conditions, especially during August and September. The average temperature and accumulated rainfall were $17.3{ }^{\circ} \mathrm{C}$ and $211.20 \mathrm{~mm}$ in 2017 , and $15.4{ }^{\circ} \mathrm{C}$ and $296.60 \mathrm{~mm}$ in 2018 , respectively, during this period. Temperatures of $10-12{ }^{\circ} \mathrm{C}$ are apparently optimal for $P$. destructor infection (Palti 1989). According to Hildebrand and Sutton (1982), relative humidity $\geq 95 \%$ is essential for sporulation of $P$. destructor. We did not observe a higher incidence of other diseases or pests that could justify lower yields in 2018. However, it was observed that the AUDPC of the control plot had a lower value in 2018, compared to 2017 . The higher rainfall in 2018 may also be related to lower yield, including the control plot. According to Kipkorir et al. (2002), the increase in deep percolation with increase in water application can cause leaching of nutrients out of the root zone, resulting in a decrease in onion yield.

The high efficiency of propineb in controlling downy mildew of onion was reported in Pakistan, where the authors found an increase in yield of $52 \%$, while Ridomil MZ® (metalaxyl-M + mancozeb) resulted in an increase of $42 \%$, when compared with control (Tahir et al. 1990). A similar trial, also in Pakistan, showed that the fungicide Melody Duo ${ }^{\circledR} 66.8$ WP (iprovalicarb and propineb), resulted in the lowest severity (91.66\% less than the control) and the highest yield (148\% higher than the control) (Iqbal et al. 2009). The greater efficiency of Antracol ${ }^{\circledR}$ (propineb), in comparison with the other protective active ingredients could be due to the amount of active ingredient per hectare. The application of Antracol $®$ resulted in $2100 \mathrm{~g}$ of active ingredient per hectare, while the application of mancozeb (Ridomil Gold ${ }^{\circledR} \mathrm{MZ}$ ) and chlorotalonil (Totalit $($ ) resulted in $1600 \mathrm{~g}$ and $562.5 \mathrm{~mL}$ of active ingredient per hectare, respectively. Also, the ineffectiveness of chlorothalonil in controlling downy mildew of onion has already been recorded (O'Brien 1992). It is unlikely that the $P$. destructor resistant population to metalaxyl or mancozeb was present in the 2018 trial, since the efficiency of these active ingredients has been proven recently (Araújo et al. 2020).

The effectiveness of propineb can also be partially explained by its protective action. The infection cycle of $P$. destructor is characterised by short periods of infection and sporulation, 1-2 days (Hildebrand and Sutton 1982). Therefore, the constant presence of a protective active ingredient on the leaf surface can prevent infections and reinfections. We will continue searching for the maximum number of active ingredients to control downy mildew of onion, in order to provide the possibility of rotation within an integrated management.

Acknowledgments This work was supported by Epagri and by funds from Conselho Nacional de Desenvolvimento Científico e Tecnológico - CNPq (409509/2018-3).

\section{Compliance with ethical standards}

The authors ensure that:

- This manuscript has not been submitted to more than one journal for simultaneous consideration.

- This manuscript has not been published previously.

- This work is not split up into several parts to increase the quantity of submissions.

- No data have been fabricated or manipulated to support our conclusions. - No data, text, or theories by others are presented as if they were the author's own.

- Consent to submit has been received explicitly from all coauthors, as well as from the responsible authorities at the institute/organization where the work has been carried out.

- Authors whose names appear on the submission have contributed sufficiently to the scientific work and therefore share collective responsibility and accountability for the results.

- Authors are strongly advised to ensure the correct author group, corresponding author, and order of authors at submission.

Conflict of interest There is no conflict of interest in the accomplishment and submission of this work. 
Table 1 Area under disease progress curve (AUDPC) and commercial yield of experimental plots of onion (cultivar "Empasc 352 - Bola Precoce"), after 10 and 12 sprays in 2017 and 2018, respectively, of different fungicides, according to the dosage recommended by the manufacturer, in order to control downy mildew, caused by Peronospora destructor, under field conditions

\begin{tabular}{|c|c|c|c|c|c|}
\hline \multirow[t]{2}{*}{ Active ingredients (a.i. dose) } & \multirow{2}{*}{$\begin{array}{l}\text { Commercial name } \\
\text { (Company) }\end{array}$} & \multicolumn{2}{|l|}{2017 trial } & \multicolumn{2}{|l|}{2018 trial } \\
\hline & & AUDPC & $\begin{array}{l}\text { Commercial yield } \\
\left(\text { ton } \mathrm{ha}^{-1}\right)^{*}\end{array}$ & AUDPC & $\begin{array}{l}\text { Commercial yield } \\
\left(\text { ton } \mathrm{ha}^{-1}\right)^{*}\end{array}$ \\
\hline propineb $\left(2100 \mathrm{~g} \mathrm{ha}^{-1}\right)$ & Antracol® (Bayer) & $130.66 \mathrm{a}$ & $32.98 \mathrm{a}$ & 168.00 & $20.70 \mathrm{a}$ \\
\hline metalaxyl-M $\left(100 \mathrm{~g} \mathrm{ha}^{-1}\right)+$ mancozeb $\left(1600 \mathrm{~g} \mathrm{ha}^{-1}\right)$ & $\begin{array}{l}\text { Ridomil Gold }{ }^{\circledR} \mathrm{MZ} \\
\quad \text { (Syngenta) }\end{array}$ & $144.66 \mathrm{a}$ & $26.23 \mathrm{~b}$ & $\begin{array}{c}\text { n.s. } \\
184.33\end{array}$ & $16.83 \mathrm{~b}$ \\
\hline $\begin{array}{l}\text { bentiavalicarb-isopropyl }\left(56.25 \mathrm{~mL} \mathrm{ha}^{-1}\right)+\text { chlorothalonil } \\
\quad\left(562.5 \mathrm{~mL} \mathrm{ha}^{-1}\right)\end{array}$ & Totalit (Ihara) & $\begin{array}{c}172.66 \\
b\end{array}$ & $23.16 \mathrm{c}$ & 186.66 & $16.55 \mathrm{~b}$ \\
\hline bentiavalicarb-isopropyl $\left(30 \mathrm{~mL} \mathrm{ha}^{-1}\right)+$ fluazinam $\left(75 \mathrm{~mL} \mathrm{ha}^{-1}\right)$ & Completto $®$ (Ihara) & $186.66 \mathrm{c}$ & $19.49 \mathrm{c}$ & n.a. & n.a. \\
\hline $\begin{array}{l}\text { bentiavalicarb-isopropyl }\left(40 \mathrm{~mL} \mathrm{ha}^{-1}\right)+\text { fluazinam } \\
\qquad\left(100 \mathrm{~mL} \mathrm{ha}^{-1}\right)\end{array}$ & Completto $®$ (Ihara) & $196.00 \mathrm{c}$ & $20.66 \mathrm{c}$ & 186.66 & $15.49 \mathrm{~b}$ \\
\hline$\beta$-aminobutyric acid $\left(250 \mathrm{~g} \mathrm{ha}^{-1}\right)$ & - & $219.33 \mathrm{c}$ & $17.04 \mathrm{~d}$ & n.a. & n.a. \\
\hline$\beta$-aminobutyric acid $\left(500 \mathrm{~g} \mathrm{ha}^{-1}\right)$ & - & $224.00 \mathrm{c}$ & $16.13 \mathrm{~d}$ & 200.66 & $12.29 \mathrm{c}$ \\
\hline$\beta$-aminobutyric acid $\left(1000 \mathrm{~g} \mathrm{ha}^{-1}\right)$ & - & $219.33 \mathrm{c}$ & $17.03 \mathrm{~d}$ & n.a. & n.a. \\
\hline pyroligneous extract $\left(500 \mathrm{~mL} \mathrm{ha}^{-1}\right)$ & - & $214.66 \mathrm{c}$ & $16.89 \mathrm{~d}$ & n.a. & n.a. \\
\hline $\begin{array}{l}\text { phosphoric acid, copper-phosphite, quaternay ammonium, } \\
\text { polymeric biguanide, acetylsalicylic acid } * *\end{array}$ & - & n.a. & n.a. & 205.33 & $12.89 \mathrm{c}$ \\
\hline water (control) & - & $219.33 \mathrm{c}$ & $16.51 \mathrm{~d}$ & 198.33 & $12.70 \mathrm{c}$ \\
\hline coefficient of variation (\%) & & 9.24 & 11.20 & 8.58 & 8.10 \\
\hline
\end{tabular}

Means in the same column and followed by the same letter did not differ according to Scott-Knott cluster analysis $(p \leq 0.05)$

n.a. $=$ not assessed

n.s. $=$ not significant difference

*Rotten bulbs and bulbs with less than $35 \mathrm{~mm}$ in diameter were not considered for yield quantification

**Concentrations not reported by the manufacturer

\section{References}

Alves DP, Araújo ER, Wamser GH, Gonçalves PAS, Marinho CD, Tomaz RS (2018) Field performance and screening for resistance to Peronospora destructor of 46 onion cultivars in Brazil. Australasian Plant Dis Notes 13:5. https://doi.org/10.1007/s13314018-0290-9

Araújo ER, Resende RS, Alves DP, Higashikawa FS (2020) Field efficacy of fungicides to control downy mildew of onion. Eur J Plant Pathol 156:305-309. https://doi.org/10.1007/s10658-019-01874-0

Epagri (2013) Sistema de produção para a cebola: Santa Catarina $\left(4^{\circ}\right.$ Revisão). Epagri. Sistema de Produção, 46). http://ciram.epagri.sc. gov.br/ciram arquivos/arquivos/cebola/acervo/sistema producao cebola_sc.pdf

Epagri/Cepa (2018) Síntese Anual da Agricultura de Santa Catarina 2017-2018. Florianópolis: Epagri. http://webdoc.epagri.sc.gov.br/ sintese.pdf

Ferreira DF (2011) Sisvar: a computer statistical analysis system. Ciênc agrotec 35:1039-1042. https://doi.org/10.1590/S141370542011000600001

Hildebrand PD, Sutton JC (1982) Weather variables in relation to an epidemic of onion downy mildew. Phytopathology 72:219-224. https://www.apsnet.org/publications/phytopathology/backissues/ Documents/1982Articles/Phyto72n02_219.PDF

Iqbal M, Sahi GM, Tahir HAS, Sahi ST, Atif M (2009) Evaluation of different fungicides against downy mildew of onion. Pak J Phytopathol 21:104-107
Kipkorir EC, Raes D, Massawe B (2002) Seasonal water production functions and yield response factors for maize and onion in Perkerra, Kenya. Agric Water Manag 56:229-240. https://doi.org/ 10.1016/S0378-3774(02)00034-3

Kurtz C, Menezes Júnior FOG, Higashikawa FS (2018) Fertilidade do solo, adubação e nutrição da cultura da cebola. Florianópolis: Epagri, p.104 (Epagri, Boletim Técnico 184) http://ciram.epagri.sc. gov.br/ciram_arquivos/arquivos/cebola/acervo/Boletim_Tecnico_ 184_Adubacao_e_nutricao_de_cebola.pdf

Mohibullah (1991) Studies on major disease of bulb vegetables (onion and garlic) in N.W.F.P. Province, Pakistan. Final Technical Report (October 1986 to September 1991). Agricultural Research Institute Tarnab (Peshawar) NWFP Pakistan

O'Brien RG (1992) Control of onion downy mildew in the presence of phenylamide-resistant strains of Peronospora destructor (Berk.) Caspary. Aust J Exp Agric 32:669-674. https://doi.org/10.1071/ EA9920669

Palti J (1989) Epidemiology, prediction and control of onion downy mildew caused by Peronospora destructor. Phytoparasitica 17:3148. https://doi.org/10.1007/BF02979603

Shaner G, Finney RE (1977) The effect of nitrogen fertilization on the expression of slow-mildewing resistance in Knox wheat. Phytopathology 67:1051-1056. https://doi.org/10.1094/Phyto-671051

Tahir M, Muhibullah, Shah M, Saifullah (1990) The effect of different spray fungicides on downy mildew and yield of onion. Sarhad J Agric 6:377-380 